\title{
0 direito à educação e sua relação com a ampliação da escolaridade obrigatória no Brasil
}

Simone de Fátima Flach*

\section{Resumo}

0 artigo propõe uma reflexão sobre a conquista do direito à educação e sua relação com a ampliação da escolaridade obrigatória no Brasil, evidenciada a partir da ampliação do Ensino Fundamental de 8 para 9 anos. Para tanto, faz-se uma exposição sobre a conquista histórica do direito à educação, procurando demonstrar como este direito vem sendo assegurado legalmente. A partir da análise de textos tanto da área educacional quanto jurídica e documentos legais, o texto procura colocar em evidência alguns avanços e limites no processo histórico de ampliação da escolaridade obrigatória no Brasil. Ao final aponta a ampliação da escolaridade obrigatória - Ensino Fundamental de 9 anos - como um avanço para a realidade educacional brasileira, alertando para os limites que a proposta pode desenvolver caso seja efetivada sem o compromisso de assegurar o respeito à infância e a educação como direito de cidadania.

Palavras-chave: Direito à educação. História do direito à educação. Ampliação da escolaridade obrigatória. Ensino fundamental de 9 anos.

\section{The Right to Education and Its Relationship With the Enlargement of Schooling in Brazil Abstract}

This article proposes a reflection on the achievement of the right to education and its relation to the expansion of compulsory education in Brazil, evidenced from the extension of the elementary school from 8 to 9 years. Thus, an exhibition of the historic achievement of the right to education is made, seeking to demonstrate how this right has been legally secured. From the analysis of texts from both legal and educational area as well as legal documents, the text aims to highlight some achievements and limitations in the historical process of the schooling expansion in Brazil. At the end, it suggests the extension of

\footnotetext{
* Mestre em Educação pela Universidade Federal do Paraná (UFPR); Doutoranda em Educação, Universidade Federal de São
} Carlos; Professora Assistente na Universidade Estadual de Ponta Grossa (UEPG). E-mail: eflach@uol.com.br 
compulsory schooling - elementary school, 9 years - as a breakthrough for the Brazilian educational reality, warning to the limits that the proposal may develop if done without the commitment to ensure respect for childhood and education as a citizenship right.

Keywords: Right to education. History of the right to education. Extension of compulsory education. 9-year basic education.

\section{El derecho a la educación y su relación con la extensión de la escolaridad en Brasil Resumen}

El artículo propone una reflexión sobre la realización del derecho a la educación y su relación con la extensión de la enseñanza obligatoria en Brasil, evidencia de la expansión de la escuela primaria de 8 para 9 años. Por lo tanto, una exposición sobre el logro histórico del derecho a la educación, tratando de demostrar cómo este derecho ha sido logrado. Del análisis de los textos legales de ámbito educativo y como documentos jurídicos, el texto tiene por objeto destacar algunos logros y limitaciones en el proceso histórico de expansión de la escolarización en Brasil. Al final sugiere la extensión de la escolaridad obligatoria - escuela primaria, 9 años - como un gran avance para la realidad educativa brasileña, advirtiendo de los límites que la propuesta puede desarrollarse si se hace sin el compromiso de garantizar el respeto de los niños y la educación como un derecho de ciudadanía.

Palabras clave: Derecho a la educación. La historia del derecho a la educación. La extensión de la enseñanza obligatoria. La educación básica de 9 años.

\section{Direito à educação: um campo a ser (re) visitado}

Para a discussão sobre a relação entre direito e educação faz-se necessário entender o direito enquanto síntese das relações sócio-históricas que os seres humanos travam enquanto sujeitos de suas existências.

É preciso entender que a constituição histórica tanto do direito como da educação, embora em constante movimento, não ocorre simultânea e linearmente, havendo momentos de avanços, estagnação e novos processos de avanços. 0 movimento histórico dos dois fenômenos, educação e direito, não está e não estará plenamente acabado, pois considerando tratar-se de processo dialético e contraditório, estão em constante transformação. Isso nos possibilita afirmar que conclusões definitivas sobre a questão são impossibilidades teóricas, uma vez que as relações humanas não podem ser conclusivas em si mesmas, visto estarem relacionadas com uma infinidade de outras questões, as quais nem sempre estão explícitas para aquele que pretende analisá-las.

Ensaio: aval. pol. públ. Educ., Rio de Janeiro, v. 17, n. 64, p. 495-520, jul./set. 2009 
Assim, por uma questão de relevância para a reflexão que se pretende, passaremos a analisar o direito à educação circunscrito ao campo das ciências jurídicas, ou seja, no campo específico da discussão do direito.

A positivação do direito à educação, desde o seu surgimento, esteve atrelada à necessidade de trabalhadores mais bem preparados para o trabalho na indústria capitalista. 0 processo de transformação da matéria-prima em produtos, possibilitado pelo desenvolvimento da maquinaria e a consequente ruptura histórica caracterizada pela Revolução Industrial possibilitaram a reivindicação e a necessidade produtiva por educação escolar.

0 processo histórico de superação da organização social centrada no campo para a organização em cidades possibilitou a mudança do eixo do modo de produção, até então baseado na agricultura e artesanato, para um processo mais elaborado e caracterizado pela organização e divisão do trabalho e o desenvolvimento de maquinaria. Nesse sentido, houve a desapropriação do trabalhador, em relação aos saberes necessários para o domínio de processo produtivo, pois esse trabalhador foi, gradativamente, impossibilitado de exercer o trabalho em sua totalidade para exercê-lo em etapas parciais. Assim, o trabalhador deixou de exercer papel central e fundamental no processo produtivo para vender sua força de trabalho em troca de um salário.

Juntamente com esse movimento histórico de transformação da organização do aparelho produtivo e social, houve a reorganização do Estado e a emergente necessidade de educação formal para todos aqueles que engrossariam a massa de trabalhadores industriais. Contudo, convém lembrar que até então, a educação formal esteve vinculada ao poder econômico, ou seja, apenas àqueles que não tinham a necessidade de produzir para sobreviver era possibilitado o acesso aos conhecimentos mais elevados, pois os demais aprendiam-no e durante o processo de trabalho.

Convém ressaltar que:

Até a Idade Média, a escrita era algo secundário e subordinado a formas de produção que não implicavam o domínio da escrita. Na época moderna, a incorporação da ciência ao processo produtivo envolve a exigência da disseminação dos códigos formais, do código da escrita. 0 direito positivo é um direito registrado por escrito, muito diferente do direito natural que é espontâneo, transmitido pelos costumes. 0 domínio da escrita se converte, assim, numa necessidade generalizada. (SAVIANI, 1994, p.156).

Dessa forma, a educação, até então organizada para atender uma parcela reduzida de indivíduos torna-se necessária e objeto integrante dos interesses coletivos, tornandose parte dos direitos das pessoas comuns. A preocupação com a educação enquanto direito de todos faz parte das discussões tanto do campo educacional como jurídico.

Ensaio: aval. pol. públ. Educ., Rio de Janeiro, v. 17, n. 64, p. 495-520, jul./set. 2009 
0 direito à educação vem sendo discutido e estudado sistematicamente pela área das ciências pedagógicas, tornando-se uma área fortalecida, também, no campo das ciências jurídicas. 0 alargamento da perspectiva de análise da educação como direito transita, necessariamente, pelo aprofundamento da discussão sobre o ser humano, de modo a entender que os homens, independente de suas condições individuais, sociais, históricas e econômicas estão circunscritos no campo da igualdade da raça humana.

Nessa perspectiva o ser humano, ao se diferenciar dos animais modificando 0 mundo natural, criou possibilidades de transformar a realidade concreta não apenas às suas necessidades presentes, mas para atender a diversidade de necessidades de seres humanos diversos e vislumbrar um futuro diferente daquele preexistente.

0 entendimento do direito carrega consigo a característica de regulamentação genérica para atender situações existentes em determinada realidade concreta, ou seja, o direito caracteriza-se por imposições, escritas ou não, estabelecidas por seres humanos para atender determinados fatos e interesses presentes. Esta regulamentação genérica não é fixa e objetiva, mas marcada de possibilidades diversas que possam assegurar determinada conduta em fatos semelhantes. Os fatos ainda não pensados ou inexistentes não necessitam de proteção específica do direito.

0 direito à educação, assim como outras possibilidades circunscritas ao campo específico, é fruto das relações multifacetadas entre os homens, sendo passivel de equívocos e impropriedades, os quais, no decurso do tempo e pautado em condições históricas e materiais se põem a nu, mostrando-se integralmente. Quando isso acontece torna-se necessária a sua revisão e adequação à realidade concreta. Nessa perspectiva, e considerando que a educação, assim como o direito, é construção histórico-social, pensar o direito à educação é sinônimo de pensar a extensão da importância dessa relação para a sociedade como um todo.

É por isso que, a reflexão sobre as relações entre educação e direito não pode ser feita desvinculada do compromisso de pensar na sociedade. Nessa medida, o direito à educação faz parte das preocupações tanto de educadores quanto de juristas, pois não se circunscreve a um campo específico.

A partir do desenvolvimento do conhecimento científico na época moderna, a educação adquire um novo significado, havendo seu aprofundamento, mesmo que isso não tenha representado avanço imediato para a população, pois o analfabetismo era fato real em todos os países, mesmo nos mais avançados para a época.

A Revolução Francesa, como marco inicial de um novo período da história da humanidade traz consigo toda uma discussão sobre o aparato jurídico de igualdade e consequente preocupação com o direito de todos à educação escolar. Inspirada na 
Revolução Americana e nas ideias iluministas, a Declaração dos Direitos do Homem e do Cidadão, de 1789, afirmou o seguinte:

I - Os homens nascem e permanecem livres e iguais perante a lei; as distinções sociais não podem ser fundadas senão sobre a utilidade comum.

XI - A livre comunicação das opiniões e dos pensamentos é um dos direitos mais preciosos do homem; todo o cidadão pode então falar, escrever, imprimir livremente; devendo responder pelos abusos desta liberdade em casos determinados pela lei.

XII - A garantia dos direitos do homem e do cidadão necessita uma força pública; essa força é então instituída para vantagem de todos e não pela utilidade particular aos quais é confiada.

0 princípio da isonomia explícito neste documento contribuiu para a inclusão dos preceitos por ele defendidos nas normas constitucionais de vários países do mundo, o que evidencia a importância da Declaração dos Direitos do Homem e do Cidadão para a evolução das normas jurídicas. Para a área educacional o princípio da isonomia traz consigo a discussão sobre o direito à educação para todos, sem distinção de qualquer espécie, fortalecendo as lutas em defesa da cidadania. A educação assume a centralidade na discussão sobre a conquista da cidadania.

Posteriormente a este documento, muitos outros, de caráter internacional reconhecem a igualdade entre os homens e garantem o acesso à educação como forma de desenvolver e garantir a cidadania dos povos. Este reconhecimento está vinculado ao desenvolvimento de numa concepção mais democrática da sociedade.

Nesse sentido, ao discutir o direito à educação, Cury (2002a, p. 246) assim assinala a questão:

Não são poucos os documentos de caráter internacional assinados por países da Organização das Nacões Unidas, que reconhecem e garantem esse acesso a seus cidadãos. Tal é o caso do art. XXVI da Declaração dos Direitos do Homem, de 1948. Do mesmo assunto ocupam-se a Convenção Relativa à Luta contra a Discriminação no Campo do Ensino, de 1960, e o art. 13 do Pacto Internacional dos Direitos Econômicos, Sociais e Culturais, de 1966.

Mais recentemente temos o documento de Jomtien, que abrange os paises mais populosos do mundo. São inegáveis os esforços levados adiante pela Unesco no sentido da universalização do ensino fundamental para todos e para todos os países.

0 que se pretende demonstrar é que a preocupação com as questões de garantia do direito à educação para

Ensaio: aval. pol. públ. Educ., Rio de Janeiro, v. 17, n. 64, p. 495-520, jul./set. 2009 
todos é um movimento que envolve não apenas àqueles ligados diretamente ao campo educacional. No campo jurídico específico esta também é uma preocupação fundante. Tanto que na segunda metade do séc. XIX o jurista alemão Rudolf von Ihering (1979, p. 238239), já demonstrava esta preocupação quando assim assinalou em sua obra:

Nosso Estado, hodiernamente, tornou obrigatório o ensino elementar, quando antes o deixava ao gosto de cada um, apenas velando por instituições em que todos podiam adquirir conhecimentos elementares. Em, temos ainda remotos, ele nem mesmo disto cuidava. Em alguns estados escravagistas da América do Norte, era, até a guerra civil, proibido, sob pena de morte, ensinar negros a ler e escrever. Destarte, temos diante de nós quatro diferentes tomadas de posição por parte do poder público com relação a uma única e mesma questão: - a garantia da finalidade na forma da coação; - viabilização dessa finalidade por meios públicos, porém sem coação; - inteira indiferença por parte do Estado; - proibição da perseguição deste objetivo em certas classes da sociedade sob pena de morte. Aplicando nosso ponto de vista das condições vitais, a última consideração da questão, sob o enfoque daqueles estados americanos escravagistas, significa: nosso estado escravagista não se compatibiliza com a instrução de escravos - se o escravo pode ler e escrever, então deixa de ser cabeça para o trabalho: torna-se homem e faz valer seus direitos de homem, ameaçando, com isso, toda a ordem a nossa ordem social, que se assenta no instituto da escravidão. Onde a vida depende das trevas, trazer a luz é um perigo mortal.

Ihering (1979) demonstra claramente a preocupação com a garantia jurídica de educação para todos. Porém, alerta para as posições tomadas pelo poder público para garantir ou não este direito. Seguindo a linha de raciocínio desse autor, podemos afirmar que os interesses não explícitos podem estar contidos em propostas que garantam este direito. Embora analisando situação específica, em dado momento histórico, o jurista alemão demonstra que a educação, dependendo da organização social, produtiva e política de determinada sociedade, pode significar avanço ou perigo para a ordem vigente, visto que ao se tornar detentor do conhecimento o povo torna-se capaz de perceber a situação em que vive e essa "luz" pode significar o fim de um modo específico de produção. A educação pode tornar-se instrumento de luta por melhores condições de vida, possibilitando a fruição da cidadania.

Ensaio: aval. pol. públ. Educ., Rio de Janeiro, v. 17, n. 64, p. 495-520, jul./set. 2009 
Considerando que a declaração e garantia de determinado direito nas normas jurídicas não equivale à sua efetivação, pois é somente na materialidade das relações humanas que as normas serão ou não colocadas em prática, a efetivação de determinada previsão legal depende, necessariamente, de ações específicas do ente responsável. A previsão de determinado direito nas normas escritas pressupõe que seja conhecida por todos, pois todos são portadores de determinado direito e isso lhes possibilita a cobrança quando não é respeitado.

Por isso, para se discutir a educação sob a luz do direito é preciso (re) visitar o campo do direito à educação para entender seu processo de formação histórica e, consequentemente, entender o presente em sua totalidade. É por isso que defendemos neste texto a necessidade de discutir a educação no campo específico do direito, pois para analisar a ampliação da escolaridade obrigatória no Brasil torna-se imprescindivel rever dentro do campo jurídico, como este direito é assegurado para que sua efetivação não assuma apenas caráter de favor político, mas possa ser entendida como avanço na conquista de direitos pela população brasileira. É preciso ir além das análises meramente pedagógicas e políticas para se entender o direito à educação em sua totalidade.

Nessa perspectiva, não basta existir uma previsão escrita do direito à educação. Assegurar escola para todos deveria ser uma constante, não apenas nos discursos políticos ou ações isoladas de determinados governos. Para além da existência de prédios escolares torna-se necessário que os indivíduos tenham acesso à essa escola, permaneçam nela e acima de tudo adquiram e desenvolvam conhecimentos. Essa premissa não é nova, mas bastante atual, pois nos Comentários à Constituição Brasileira de 1946, 0 jurista brasileiro Pontes de Miranda (1953, p. 157), assim se expressava:

A ingenuidade ou a indiferença ao conteúdo dos enunciados com que os legisladores constituintes lançam a regra "A educação é direito de todos" lembra-nos aquela Constituição espanhola em que se decretava que todos "os Espanhóis seriam" desde aquele momento, "buenos". A educação somente pode ser direito de todos se há escolas em número suficiente e se ninguém é excluído delas, portanto se há direito público subjetivo à educação e o Estado pode e tem de entregar a prestação educacional. Fora daí, é iludir com artigos de Constituição e de leis. Resolver o problema da educação não é fazer leis, ainda excelentes; é abrir escolas, tendo professores e admitindo alunos.

Por isso, discutir educação e direito ultrapassa a mera exposição da previsão legal, através de enumeração de dispositivos legais que versam sobre a questão, mas ir além do ordenamento jurídico positivo e entender as contradições da realidade concreta.

Ensaio: aval. pol. públ. Educ., Rio de Janeiro, v. 17, n. 64, p. 495-520, jul./set. 2009 


\section{Direito à educação e obrigatoriedade escolar no Brasil: entre a previsão legal e a realidade}

Devido à formação histórica brasileira e aos embates ideológicos ocorridos tanto no campo educacional quanto social e jurídico, o direito à educação no Brasil demonstra-se, atualmente, como o resultado de múltiplas influências que sofreu ao longo de sua elaboração.

0 processo histórico brasileiro decorrente da colonização portuguesa e da forma como esta entendeu a ocupação do território, contribuiu para o fortalecimento do poder dos proprietários de terras, através do isolamento e da estratificação social. A organização social transplantada de Portugal para o Brasil pressupunha um pequeno grupo de detentores de terra que se impunham sobre uma massa de agregados e escravos. Neste sentido nos esclarece Faoro (2001, p. 238):

A tradicional visão da sociedade da colônia dos dois primeiros séculos reduz as classes a duas, senão a uma, em dois pólos extremos: o proprietário rural, com engenhos e fazendas, contraposto à massa de trabalhadores do campo, escravos e semilivres. 0 proprietário rural, com a economia assentada na sesmaria latifundiária, ganharia status aristocrático, em simbiose com a nobreza de linhagem. Mais um passo: 0 'aristocrata' comandaria a vida política local, controlando e calando muitas vezes a supremacia administrativa reinol.

Iniciada dessa forma a organização social brasileira não favoreceu o desenvolvimento de pensamento que centrasse a educação como direito da totalidade da população. Nem mesmo a educação foi vista como necessária durante o periodo anterior à República.

A instrução em si não representava grande coisa na construção da sociedade nascente. As atividades de produção não exigiam preparo, quer do ponto de vista de sua administração, quer do ponto de vista da mão de obra. 0 ensino, assim, foi conservado à margem, sem utilidade prática visível para uma economia fundada na agricultura rudimentar e no trabalho escravo (ROMANELLI, 1986, p. 34).

Durante o periodo colonial brasileiro pouco se fez para possibilitar acesso à escola para o povo. A colônia durante mais de três séculos nada mais foi do que a "vaca de leite" da metrópole, conforme palavras de Raimundo Faoro (2001). Visto apenas como possibilidade de angariar riquezas, o Brasil não foi alvo de preocupação em relação ao direito à educação. Mesmo após a vinda da familia real portuguesa para o Brasil, as instituições educacionais criadas visavam a preparar quadros específicos de nível avançado; ou seja, a criação de escolas para a população foi praticamente inexistente, sendo relegada a um segundo plano, não havendo expansão significativa em relação à sua oferta. 
Nesse sentido, a educação brasileira ficou sujeita aos interesses pessoais e políticos daqueles que detinham o poder. A população pouco esperava que sua educação fosse assegurada pelo poder público; muito menos que viesse a se constituir um direito. Apenas à elite era possibilitado o acesso ao ensino. A submissão do povo, tanto ao Soberano como aos senhores de terra foi bastante marcante, sufocando possiveis descontentamentos em relação à ordem vigente ou manifestações de reivindicação do direito à educação.

Após a Independência, os constituintes brasileiros influenciados pela Constituição Francesa de 1791, apresentam em $1^{\circ}$ de setembro de 1823, um projeto de Constituição o qual previa

a difusão da instrução pública de todos os níveis, salientando a responsabilidade do governo e consagrando expressamente a liberdade da iniciativa particular chamada a cooperar com os poderes públicos na difusão das luzes por todas as camadas da população (HAIDAR; TANURI, 1999, p. 62).

Embora a Constituição de 1824 (BRASIL, 2003a) não tenha previsto em seus artigos os anseios da Assembleia de 1823, estes não foram totalmente ignorados, pois a Carta outorgada em 1824 previa em seu art. 179:

Art. 179 [...]

XXXI - A instrução primária é gratuita a todos os cidadãos. XXXII - Colégios e Universidades, aonde serão ensinados os elementos das Ciências, Bellas Artes e Artes.

Apesar da previsão constitucional o quadro geral da educação pública pouco se alterou. A educação elementar ainda esteve condenada aos interesses dos governantes: algumas escolas primárias foram criadas e os estudos médios estavam organizados em aulas avulsas. Nesse contexto, de parcas escolas, embora a Carta Magna previsse a educação como direito, assegurando inclusive que a educação elementar seria gratuita, o direito à educação não se constituiu em possibilidade prática, pois a população continuou sem qualquer oportunidade de acesso ao ensino formal. Assim, à população em geral restava - consideremos que alguns poucos indivíduos - conseguir alcançar os rudimentos da leitura e da escrita, sem maiores possibilidades de avanço no processo educativo. Este é o quadro educacional herdado pela República após quase quatro séculos de colonização e império português no país. Àqueles que realmente trabalharam na construção do país em formação, pouco ou quase nada lhes foi assegurado em matéria de direitos e àqueles que enriqueceram às custas da exploração do trabalho escravo de negros, índios e dos desprovidos de qualquer bem material, tudo poderiam conseguir, graças ao poder que detinham na sociedade da época.

A educação nos primeiros anos da República manteve-se inalterada, pois a dualidade de sistemas continuou como no Império. No âmbito prático, o sistema de ensino elementar ficou sob a responsabilidade dos Estados, dentro de suas possibi-

Ensaio: aval. pol. públ. Educ., Rio de Janeiro, v. 17, n. 64, p. 495-520, jul./set. 2009 
lidades financeiras. Entregues à própria sorte, os Estados passaram a organizar sistemas independentes, o que contribuiu para uma completa desorganização quanto à garantia do direito à educação para a população.

A educação elementar, ao que nos parece, não preocupava o governo republicano. Isso pode ser evidenciado pela rápida existência do Ministério da Instrução Pública, Correios e Telégrafos, em 1890. A própria população não via a educação como necessária. A estrutura social vigente legitimava a herança do modelo educacional imperial.

Para uma economia de base agrícola, como era a nossa, sobre a qual se assentavam o latifúndio e a monocultura e para cuja produtividade não contribuía a modernização dos fatores de produção, mas tão somente se contava com a existência de técnicas arcaicas de cultivo, a educação realmente não era considerada como fator necessário (ROMANELLI, 1986, p. 45).

Apesar de o sistema educacional ser precário devido aos fatores sociais, econômicos, politicos e culturais, a oferta atendia a demanda conforme as necessidades do pais em formação. Todavia o indice de analfabetismo brasileiro foi extremamente alto (chegando a $74,59 \%$, em 1900).

A organização educacional entra em crise a partir do momento em que o modelo existente se choca frontalmente com o ideário republicano de participação politica. A República estava inviabilizada de atender a demanda educacional de forma qualitativa. Algumas décadas foram necessárias para que o pensamento sobre 0 direito à educação para todos fosse evidenciado nos discursos políticos e sociais.

0 processo de urbanização, ao qual o pais iniciava, foi a alavanca inicial para a reivindicação de mudança na organização educacional vigente na época. Também contribuiu para essa nova realidade a exigência do setor produtivo por recursos humanos. Com isso houve um elevado aumento da demanda social de educação.

A pequena oferta e um ensino que não correspondia às exigências da expansão econômica são fatores que demonstram uma desorganização do sistema e a necessidade de mudança, tanto de ordem quantitativa quanto qualitativa na educação oferecida. Outro fator que precisa ser evidenciado é o clima cultural em que se discutiam as questões educacionais. 0 entusiasmo pela educação e otimismo pedagógico marcam o decênio de 20, através dos quais a educação passa a ser vista como a mola propulsora para o progresso e o desenvolvimento. E para conseguir tal intento a educação passa a ser definida por educadores profissionais, constituindo uma área técnica. Também é necessário evidenciar a criação da Associação Brasileira de Educação (ABE) em 1924, a qual propôs discussões em nivel nacional sobre a educação escolar. Muitas ideias discutidas neste âmbito viriam a consubstanciar o Manifesto dos Pioneiros da Educação Nova em 1932 e a Constituição Federal de 1934.

Ensaio: aval. pol. públ. Educ., Rio de Janeiro, v. 17, n. 64, p. 495-520, jul./set. 2009 
Em 1932, com a publicação do "Manifesto dos Pioneiros da Educação Nova" (AZEVEDO et al., [2007]), endereçado ao povo e ao governo, há o reconhecimento da educação como direito de todos e dever do Estado através da reivindicação de uma escola pública assentada nos princípios de laicidade, obrigatoriedade, gratuidade e coeducação. Este documento aponta para a necessidade de uma reconstrução educacional no Pais, sendo, inclusive as ideias defendidas no documento apresentadas no anteprojeto à Assembleia Constituinte.

A Constituição de 1934, considerada bastante progressista em relação à educação, irá estabelecer a necessidade de um plano nacional de educação, ensino gratuito e obrigatório, além de prever percentuais de receitas e impostos para a manutenção e desenvolvimento do ensino. Porém, é preciso ressaltar que esta Constituição teve uma vida efêmera, não chegando a consolidar os princípios por ela assegurados, pois tendo em vista o agravamento da situação político-social no pais onde há um combate das ideias populares, aliadas ao comunismo e ao antifacismo, ocorre a aprovação da Lei de Segurança Nacional em 1935, instituindo permanente estado de sítio no pais.

Em 1937 uma nova Constituição é outorgada para o País. Em consequência do golpe, a 10 de novembro é outorgada uma nova Constituição, que difere em essência das anteriores constituições republicanas, pois dispensava o sistema representativo, enquadrava os demais poderes no Executivo e liquidava com o federalismo, com os governos estaduais, com a pluralidade sindical, etc. Em um de seus artigos, o de $n^{\circ} 177$ das disposições Transitórias, que foi prorrogado por duas vezes, permitia ao governo aposentar ou demitir funcionários considerados contrários ao governo (RIBEIRO, 1991, p.114).

Em relação ao direito à educação a Constituição de 1937 restringe os deveres do Estado na manutenção do ensino eliminando muitas das conquistas ocorridas anteriormente. Nesse sentido a Constituição (BRASIL, 2003b) prevê:

Art. 125. A educação integral da prole é o primeiro dever e direito natural dos pais. 0 Estado não será estranho a esse dever, colaborando, de maneira principal ou subsidiária, para facilitar a sua execução ou suprir as deficiências e lacunas da educação particular.

Dessa forma o texto legal considera a educação como "dever e direito natural dos pais" eximindo-se dessa responsabilidade ao prever que "não será estranho a esse dever", sem objetivar a forma como isso ocorrerá. Ainda, outro dispositivo constitucional (BRASIL, 2003b) prevê:

Art. 130. 0 ensino primário é obrigatório e gratuito. A gratuidade, porém, não exclui o dever de solidariedade dos

Ensaio: aval. pol. públ. Educ., Rio de Janeiro, v. 17, n. 64, p. 495-520, jul./set. 2009 
menos para com os mais necessitados; assim, por ocasião da matrícula, será exigida aos que não alegarem, ou notoriamente não puderem alegar escassez de recursos, uma contribuição módica e mensal para a caixa escolar.

A história nos mostra que, no emaranhado de acontecimentos econômicos, políticos e sociais pelos quais o país passava, a educação do povo foi relegada a segundo plano.

Em 1945 inicia-se a chamada redemocratização do país. Uma nova Constituição é promulgada em 1946 (BRASIL, 2003c), a qual, em essência, não se diferencia da Constituição de 1934.

Dentre os principios assegurados pela Carta Magna de 1946, no art. 168 (BRASIL, 1946c), a obrigatoriedade e a gratuidade do ensino primário figuram como grandes avanços, no sentido de garantir à população mais pobre acesso à educação escolar.

Em 20 de dezembro de 1961 é sancionada a Lei de Diretrizes e Bases da Educação Nacional (BRASIL, 1961), dando-se um grande passo para a unificação do ensino no pais. Todavia, esta não vai modificar substancialmente o sistema educacional, pois nenhuma modificação profunda ocorre apenas com sua previsão legal.

Esta lei previa a obrigatoriedade da educação escolar, apontando para o avanço em relação à declaração do direito à educação:

Art. 27. 0 ensino primário é obrigatório a partir dos sete anos e só será ministrado na língua nacional. Para os que o iniciarem depois dessa idade poderão ser formadas classes especiais ou cursos supletivos correspondentes ao seu nível de desenvolvimento (BRASIL, 1961).

Porém, convém lembrar que:

a preocupação central da lei quanto à obrigatoriedade da frequência à escola primária, condição mínima básica para a existência de qualquer regime democrático, era praticamente nula, sobretudo, se se tiver em conta a realidade social brasileira (ROMANELLI, 1986, p. 181).

Como se vem evidenciando ao longo da história brasileira as ações do poder público são limitadas no sentido de corrigir ou diminuir o problema com a educação popular, tanto em termos quantitativos quanto qualitativos.

Em 1962 o Conselho Federal de Educação aprovou o Plano Nacional de Educação que tinha, dentre inúmeras metas, a de garantir a matrícula até a quarta série de 100\% da população escolar de 7 a 11 anos. Passados, hoje, quase meio século, o Brasil ainda não conseguiu atingir a meta estabelecida por este Plano Nacional de Educação.

Ensaio: aval. pol. públ. Educ., Rio de Janeiro, v. 17, n. 64, p. 495-520, jul./set. 2009 
A extensão da escolaridade parece ter sido uma meta bastante importante, mas a produtividade do sistema deixou a desejar, pois os altos índices de reprovação faziam com que os alunos permanecessem no sistema sem avanços significativos.

Assim sendo, parece-nos lícito afirmar, mais uma vez, que a manutenção do atraso da escola em relação à ordem econômica e à ordem social, longe de ser uma condição de fato, era uma decorrência da forma como se organizava o poder e, portanto, servia aos interesses dos grupos nele mais notavelmente representados (ROMANELLI, 1986, p. 191).

Durante o período de ditadura militar e sob a égide da Constituição de 1967, reformulada pela Emenda Constitucional n ${ }^{\circ} 1$ de 17 de outubro de 1969, o direito à educação no Brasil não sofreu mudanças substanciais, o que demonstra a desconsideração do novo regime pela instrução e formação intelectual da população. Sob a influência dos acordos internacionais e após 13 anos de tramitação no Congresso Nacional, em 1971 é aprovada a Lei 5692, que propõe uma reforma no ensino de $1^{\circ}$ e $2^{\circ}$ graus. Para 0 objetivo deste texto convém ressaltar o disposto logo no início da referida lei:

Art. $1^{\circ} .0$ ensino de $1^{\circ}$ e $2^{\circ}$ graus tem por objetivo geral proporcionar ao educando a formação necessária ao desenvolvimento de suas potencialidades como elemento de autorealização, qualificação para o trabalho e prepara para o exercício consciente da cidadania. (BRASIL, 1971).

Para cumprir este objetivo é realizada uma reestruturação do ensino, a que nos demonstra que a maior importância é a ampliação da obrigatoriedade escolar de 4 para 8 anos, através da fusão dos cursos primário e ginásio, visando a extinguir a seletividade existente pelo exame de admissão, ainda existente. Desta forma institui-se a obrigatoriedade escolar para os alunos de 7 a 14 anos Em relação a educação enquanto direito da população, a iniciativa pode ser considerada como um avanço. Porém, a obrigatoriedade prevista torna-se letra morta, pois não existiam recursos materiais e humanos para atender à demanda existente.

A lei privilegiou um enfoque quantitativo e não considerou aspectos elementares para afiançar a qualidade do ensino, tais como a necessidade de rever a organização da escola e as próprias condições de efetivação real do ensino básico. $\mathrm{Na}$ verdade, o regime militar diminuiu drasticamente os recursos para a educação, que alcançaram os baixos indices de aplicação da história recente do país, menos de $3 \%$ do orçamento da União. 0 salário-educação (Lei 4420/64), originariamente concebido com o objetivo de incrementar 0 ensino oficial de $1^{\circ} \mathrm{grau}$, cumpriria o papel de principal fonte de recursos para fazer frente às necessidades do ensino fundamental. Adicionalmente, garantia apoios políticos mais fortes e seguros ao regime. A União, ao repassar recursos do salário-educação aos estados da Federação para a constru-

Ensaio: aval. pol. públ. Educ., Rio de Janeiro, v. 17, n. 64, p. 495-520, jul./set. 2009 
ção de escolas, atendia a interesses de políticos e empreiteiros locais, criando, dessa forma, uma rede de favores e dependências. Por outro lado, as verbas do salário-educação, gradativamente, foram aplicadas para subsidiar o ensino privado. No momento, então, em que a escola básica com oito anos de obrigatoriedade exigia uma intervenção clara em seus desdobramentos, fortes investimentos para sua implementação em todo território nacional, ampla discussão com educadores e educadoras de todo o país, o governo limitouse a ampliar o clientelismo e a formular projetos de gabinete (SHIROMA; MORAES; EVANGELISTA, 2000, p. 39).

É importante ressaltar que a grande maioria dos iniciantes do $1^{\circ} \mathrm{grau}-\mathrm{em}$ torno de $80 \%$ - não conseguia sobreviver ao sistema e iniciar o $2^{\circ} \mathrm{grau}$, o que demonstra uma organização escolar que não conseguiu atingir o objetivo de assegurar o direito à educação à população. Mais uma vez fica demonstrado que a previsão legal não garante o direito de estar e aprender na escola. A organização escolar seriada, a cultura de privilégio aos melhores contribui para que o acesso à escola seja mero detalhe na garantia do direito à educação. Estar na escola não significa, necessariamente, estar aprendendo na escola. Os limites internos da organização escolar e as condições externas impedem que os alunos avancem e usufruam a oportunidade de acesso à escola.

Em meados da década de 1980, o quadro educacional brasileiro era dramático: $50 \%$ das crianças repetiam ou eram excluídas ao longo da $1^{\text {a }}$ série; $30 \%$ da população eram analfabetos, 23\% dos professores eram leigos e 30\% das crianças estavam fora da escola. Além disso, 8 milhões de crianças no $1^{\circ}$ grau tinham mais de 14 anos, 60\% de suas matrículas concentravam-se nas três primeiras séries que reuniam 73\% das reprovações. Ademais, é importante lembrar que $60 \%$ da população brasileira viviam abaixo da linha da pobreza. Tais dados forneciam as condições para a exigência de redirecionamento na legislação educacional vigente (SHIROMA; MORAES; EVANGELISTA, 2000, p. 44).

Cresceram os movimentos em prol de mudanças no sistema educacional, firmando-se a concepção da educação pública e gratuita como direito público subjetivo e dever do Estado em assegurar tal direito. Aos poucos vai-se constituindo uma nova política educacional, contrária àquela que ocorreu nos governos militares e, em 1988, o povo brasileiro terá uma nova Constituição (BRASIL, 2003d), esta agora elaborada, supostamente, sob uma organização de Estado Democrático de Direito.

Nesse sentido, uma Constituição não se elabora ao simples prazer dos legisladores, mas representa as reivindicações, as aspirações dos diversos segmentos

Ensaio: aval. pol. públ. Educ., Rio de Janeiro, v. 17, n. 64, p. 495-520, jul./set. 2009 
da sociedade civil. Ela representa o resultado das correlações de forças, muitas vezes antagônicas, que refletem a vontade de uma nação. Isso ficou evidenciado, também, no caso brasileiro.

A Constituição de 1988 tentou dar conta das profundas mudanças ocorridas em nosso país na economia, nas relações de poder e nas relações sociais globais, nos últimos 20 anos, introduzindo temas, redefinindo papéis, incorporando às instituições sociais segmentos historicamente marginalizados, sem, no entanto, alterar substantivamente as relações sociais vigentes (NEVES, 1999, p. 99).

Isso se justifica devido ao empenho do governo da época em direcionar suas ações baseadas num discurso de "tudo pelo social", além de ter o compromisso em romper com as amarras do militarismo ainda presente. A Constituição Federal de 1988 (BRASIL, 2003d) significou o resultado da correlação de forças entre o processo de reabertura política e 0 avanço neoliberal já em curso. Logo em seu preâmbulo, a Constituição anuncia a instituição de um Estado Democrático, destinado a assegurar, dentre outros preceitos, o exercício dos direitos sociais e individuais como valores supremos de uma sociedade.

0 Estado Democrático de Direitos pressupunha a ampliação dos direitos sociais. A Constituição da transição, além de delimitar, modernizando, o arcabouço institucional das relações econômicas, teve seu ponto de inflexão na delimitação dos marcos institucionais de maior socialização do poder (NEVES, 1999, p. 100).

0 Estado democrático de Direito (BRASIL, 2003d) é previsto no parágrafo único do art. $1^{\circ}$ que diz: "Todo o poder emana do povo, que exerce por meio de representantes eleitos ou diretamente, nos termos desta Constituição". Ao declarar que "todo poder emana do povo", a Constituição assegura de forma ampla a soberania popular.

É dessa potência que se pode entender por que a legislação ganha sentido, legitimidade e prestígio. Contrariamente à lei da força, a força da lei é a ordem jurídica nascida da vontade popular que vai se impondo como o modo normal de funcionamento da sociedade, como lugar de igualdade de todos e como produto da própria cidadania. Será, pois, no reconhecimento da cidadania como capacidade alargar o horizonte de participação de todos nos destinos nacionais que a legislação volta à cena (CURY, 2002b, p.17).

0 reconhecimento da cidadania no texto constitucional conduz à compreensão de que ela se constitui em "um ato pelo qual se dá a todos o conhecimento da legislação em termos de direitos, deveres, obrigações e proibições, além do funcionamento organizacional de uma sociedade." (CURY, 2002b, p. 17). Sendo o ordena-

Ensaio: aval. pol. públ. Educ., Rio de Janeiro, v. 17, n. 64, p. 495-520, jul./set. 2009 
mento jurídico primeiro, a partir do qual se fundamentam todas as demais leis e normatizações, a Constituição assume papel de destaque no ordenamento legal no País. Neste sentido seria necessário que todos conhecessem a legislação organizadora da vida individual e coletiva, mas num país profundamente excludente, como é o Brasil, esta exigência se torna irreal, já que a grande maioria da população brasileira não tem acesso aos bens culturais, e muito menos à compreensão sobre a importância do conhecimento do ordenamento jurídico. Somente aos mais instruidos e pertencentes a uma classe social elevada é reconhecido o direito de conhecer os preceitos legais. Isso é considerado "normal" numa sociedade como a brasileira, pois os mais pobres e menos letrados continuam excluídos das discussões sobre a organização do País. E há, ainda, muitos analfabetos.

Para efeito deste estudo, mostra-se essencial que o capítulo III da Constituição Federal, na seção intitulada "Da Educação", seja aqui abordado, no intuito de tornar mais clara a compreensão de direito à educação assegurado na Carta Magna.

Antes mesmo do capítulo que trata especificamente da Educação, a Constituição (BRASIL, 2003d) assim assinala:

Art. $6^{\circ}$ São direitos sociais a educação, a saúde, o trabalho, o lazer, a segurança, a previdência social, a proteção à maternidade e à infância, a assistência aos desamparados, na forma desta Constituição.

A educação é, assim, "um direito social fundante da cidadania e o primeiro na ordem das citações" (CURY, 2002a). Isso equivale dizer que sem educação não pode haver cidadania. Também o pleno exercício da democracia encontrar-se-á entravado se este direito social não for amplamente assegurado à população.

Cury (BRASIL, 2002a) aponta ainda outros direitos assegurados constitucionalmente, mas que dependem da efetivação do direito à educação.

É importante se saber, por exemplo, que o Título II, Capítulo I, art. $5^{\circ}$ da nossa Constituição garante uma lista infinda de direitos civis dentre os quais muitos tem a ver com educação. Cito alguns: a igualdade jurídica entre homem e mulher, a liberdade de consciência e de expressão, a liberdade de associação, a condenação a todo tipo de maus-tratos e a condenação ao racismo como crime inafiançável (CURY, 2002b, p. 19).

Sendo assim, a educação colocada como direito de todos e dever do Estado e da família é entendida como primordial para o desenvolvimento do ser humano, para que este exerça plenamente a cidadania e, de quebra, obtenha qualificação para o trabalho. 0 status dado à educação é tão importante que o ensino gratuito e

Ensaio: aval. pol. públ. Educ., Rio de Janeiro, v. 17, n. 64, p. 495-520, jul./set. 2009 
obrigatório (ensino fundamental) tornou-se direito público subjetivo nos parágrafos $1^{\circ}$ e $2^{\circ}$ do art. 208 da Carta Magna brasileira (BRASIL, 2003d):

$\S 1^{\circ} 0$ acesso ao ensino obrigatório e gratuito é direito público subjetivo.

$\S 2^{\circ} 0$ não-oferecimento do ensino obrigatório pelo Poder Público, ou sua oferta irregular, importa responsabilidade da autoridade competente.

Em linhas gerais, como afirma Reale (1988, p. 261), "o direito subjetivo representa a possibilidade de exigir-se, como próprios, uma prestação, ou um ato de maneira garantida, nos limites atributivos das regras de direito". Nesse sentido, entender a educação enquanto direito público subjetivo implica afirmar que o indivíduo possui uma esfera de ação inviolável, na qual o Poder Público não pode penetrar. Assim, são esclarecedoras as palavras de Reale (1988, p. 264):

É que, no fundo, todos os direitos públicos subjetivos pressupõem o direito fundamental de liberdade, entendida em sua dupla valência, como poder autônomo de ser e agir na esfera privada (liberdade civil) e na esfera pública (liberdade política). (destaques no original).

Direito público subjetivo é, portanto, "aquele pelo qual o titular de um direito pode exigir direta e imediatamente do Estado, o cumprimento de um dever e de uma obrigação". (CURY, 2002b, p. 21).

Em matéria de educação, assegurada constitucionalmente, o titular desse direito é uma pessoa de qualquer idade, que teve ou não acesso à escolaridade obrigatória na idade própria. 0 sujeito deste direito é o indivíduo e o sujeito do dever é o Estado, sob cuja competência estiver esta etapa de escolaridade.

Na prática, isto significa que o titular de um direito público subjetivo tem assegurado a defesa, a proteção e a efetivação imediata de um direito, mesmo quando negado. Qualquer criança, adolescente, jovem ou idoso que não tenha entrado no ensino fundamental pode exigi-lo e o juiz deve deferir direta e imediatamente, obrigando as autoridades constituídas a cumpri-lo sem mais demora. 0 não cumprimento por parte de quem de direito quanto a isto implica responsabilidade da autoridade competente (CURY, 2002b, p. 22).

Todavia, novamente é preciso lembrar que, numa sociedade como a brasileira, isto fica praticamente inviabilizado, pois, não sabendo da possibilidade de exercer tal direito, os indivíduos ficam incapacitados de exigi-los. 0 poder econômico demonstra-se como determinante na efetivação dos preceitos constitucionais, ou seja, aos excluídos, das esferas social e econômica, fica dificultado o exercício da própria cidadania. 
Após a declaração, no texto constitucional do direito à educação à totalidade da população, convém analisar sob quais princípios a educação e o ensino estão assentados. 0 artigo 206 (BRASIL, 2003d) elenca alguns princípios sob os quais o ensino deve ser ministrado e dentre os quais podemos destacar os seguintes, por estarem diretamente vinculados à temática em questão neste texto:

Art. 206. 0 ensino será ministrado com base nos seguintes principios:

I - igualdade de condições para o acesso e permanência na escola:

[...]

IV - gratuidade do ensino público em estabelecimentos oficiais; [...]

0 cumprimento destes princípios, ao que parece, está ligado à garantia do direito à educação, pois há a previsão de igualdade de condições e não igualdade de oportunidades para o acesso e permanência na escola, evidenciando-se a preocupação do legislador em assegurar educação para todos. Todavia, para atender o inciso I, tornase necessário uma nova reorganização social, pois a maneira excludente sob a qual se edifica a sociedade brasileira torna este dispositivo com poucas possibilidades de efetivar-se de maneira prática. A oferta de educação para todos fica, no âmbito prático, circunscrita à igualdade de oportunidades, pois a igualdade de condições necessita muito mais do que a simples previsão legal, necessita de outra forma de organização social, política e econômica, a qual ainda não foi alcançada pela sociedade brasileira.

Assim, os pobres, que são a maioria da população brasileira, ficam totalmente dependentes das políticas sociais compensatórias para que a previsão constitucional tenha alguma possibilidade de efetivamente ser cumprida.

0 inciso IV do art. 206 (BRASIL, 2003d) prevê, a gratuidade do ensino público, o que implica o ensino ser oferecido sem nenhum tipo de ônus, seja pecuniário ou não. Todavia, a prática dos estabelecimentos escolares da rede pública é a de estabelecer um pagamento através da "taxa de contribuição espontânea", cobrada através das APMs, ou solicitar "doações" aos alunos e comunidade para a aquisição de materiais ou pequenos bens para os estabelecimentos.

Segundo Paro (1996), inúmeros argumentos podem ser colocados contra ou a favor de tais cobranças ocorridas no contexto escolar.

Os vários argumentos a favor e contra a existência da APM com sua função arrecadadora de recursos da população colocam-se diante de um sério dilema. Por um lado, não há dúvida nenhuma que a população deve ter o direito a educação escolar de boa qualidade, sendo,

Ensaio: aval. pol. públ. Educ., Rio de Janeiro, v. 17, n. 64, p. 495-520, jul./set. 2009 
portanto uma perversidade cobrar (por meio da APM) por um serviço pelo qual ela já pagou, quer por meio dos impostos, quer por meio da exploração inerente às relações capitalistas de produção. Por outro lado, depara-se com a realidade de uma quase totalidade de pais, alunos, professores e funcionários favoráveis à cobrança da taxa com a finalidade de remediar um pouco o descalabro da situação escolar. Esse impasse parece delinear uma situação limite para a qual não cabem soluções simplistas. (PARO, 1996, p. 137).

Na prática, a gratuidade do ensino público não é "tão gratuita" assim, pois o ônus existe, seja velado ou não, através de doações e contribuições espontâneas ou quaisquer outras denominações que sejam criadas para justificar sua necessidade. 0 que precisa ser evidenciado é que a busca de recursos junto à sociedade em geral demonstra a desobrigação do Estado com a educação pública, seja através da não destinação dos recursos necessários ou mesmo a má administração dos recursos públicos.

Os dispositivos constitucionais são impositivos e não facultativos e assim demonstram uma intencionalidade de efetivação, dando o perfil da educação brasileira para a atualidade.

A Constituição deve, em tese, ser conhecida de todos e efetivamente cumprida. A qualidade da educação brasileira está prevista e se traduz no conjunto de ações que necessitam ser colocadas em prática e não apenas constarem do texto escrito. Eis aqui algumas contradições existentes entre aquilo que se prevê e o que efetivamente é colocado em prática. Os preceitos constitucionais devem-se realizar na materialidade concreta, ou seja, na realidade brasileira, possibilitando um avanço qualitativo nos processos educacionais.

Um Brasil uno em sua multiplicidade, moderno e efetivamente democrático será realidade quando oferecer ao seu povo reais condições de inclusão e cidadania. Isso possibilitará o rompimento com uma realidade perversa e dualista de um passado ainda presente. (CURY, 2002b).

Embora a Constituição Brasileira possa estar eivada de contradições, se suas prescrições forem vivenciadas concretamente pela totalidade da sociedade, poderão ser desenvolvidos indicativos que contribuam para uma superação da realidade excludente, na qual a maioria da população se encontra.

As alterações legais específicas, no tocante ao direito à educação, ocorridas a partir da década de 90 , serão expostas e analisadas em conjunto com a proposta de ampliação da escolaridade obrigatória a ser analisada.

Ensaio: aval. pol. públ. Educ., Rio de Janeiro, v. 17, n. 64, p. 495-520, jul./set. 2009 


\section{A ampliação da escolaridade: um direito de cidadania para a população brasileira}

No Brasil a educação se vem mostrando não apenas necessária, mas medida possivel de oferecer aos indivíduos oportunidades de contato com o mundo do conhecimento sistematizado dando-Ihes os meios necessários para entender a ordem vigente, com vistas à sua superação. Em uma sociedade desigual como a brasileira, onde a organização escolar tem estreita vinculação com o sistema capitalista mundial, garantir o contato e domínio dos conhecimentos historicamente produzidos é central para o desenvolvimento da cidadania.

Tanto a Constituição Federal de 1988 (BRASIL, 2003d) como a Lei de Diretrizes e Bases da Educação Nacional (BRASIL, 1996), prevê a obrigatoriedade e gratuidade da escola pública para o ensino fundamental. Embora estes dispositivos legais não sejam garantia de mudança na realidade existente, podem ser considerados como um avanço, ainda mais quando se cria a possibilidade de que o ensino fundamental tenha maior duração.

A possibilidade de atendimento ampliado surge quando é aprovado o Plano Nacional de Educação, com a Lei no. 10.172, de 9 de janeiro de 2001 (BRASIL, 2001), que ao fazer um diagnóstico do Ensino Fundamental no país e analisar a situação do inchaço de matrículas neste nível de escolaridade causada pela distorção idade-série, aponta para a possibilidade de um ensino fundamental com duração de nove anos. 0 mesmo documento, estabelecendo objetivos e metas para o Ensino Fundamental, propõe:

Ampliar para nove anos a duração do ensino fundamental obrigatório com início aos seis anos de idade, à medida que for sendo universalizado o atendimento na faixa de 7 a 14 anos (BRASIL, 2001).

Evidencia-se, portanto, uma preocupação com a necessidade de oportunizar mais tempo na escola para os alunos do ensino fundamental, ampliando-se a duração do mesmo. Todavia, Arelaro (2005, p. 1046) alerta para os interesses que possam estar implícitos nesta proposta:

É importante destacar as dificuldades que poderão advir dessa decisão política, pois dos 34,5 milhões de alunos matriculados no ensino fundamental regular do Brasil, somente 520 mil deles já vêm iniciando seus estudos aos 6 anos de idade. 0 que gera dois tipos de questões: a primeira, sobre a origem dessa proposta, defendida pelo governo anterior e expressa no Plano Nacional de Educação (PNE), plano este elaborado por esse mesmo governo e aprovado nas férias docentes de 2001 (Lei n. 10.172, de 9/1/2001). Se o governo anterior não defendia e educação infantil, como responsabilidade

Ensaio: aval. pol. públ. Educ., Rio de Janeiro, v. 17, n. 64, p. 495-520, jul./set. 2009 
do Estado, propondo inclusive que as parcerias com a comunidade fossem a forma de expansão desse atendimento, é possivel que, assumindo um ano a "mais" no ensino fundamental, os outros anos dela - de 0 a 5 - eventualmente pudessem ser assumidos pelas comunidades.

Essa preocupação mostra-se importante no contexto político educacional brasileiro visto que inúmeras propostas implementadas mostraram-se ineficazes em relação ao compromisso de assegurar o direito à educação de milhares de brasileiros.

0 ingresso das crianças mais cedo no ensino obrigatório atende a uma política de equidade social, principalmente num pais onde esse segmento da educação foi marcado historicamente pelo descompromisso governamental, que sempre atendeu aos interesses das classes dominantes. Contudo, essa opção precisa ser avaliada com cuidado, para não incorrer numa "inclusão excludente": um maior número de crianças estará dentro da escola, sem que esta esteja pedagógica, financeira e estruturalmente preparada para receber tais alunos.

0 ensino fundamental, conforme previsto constitucionalmente, é obrigatório e gratuito, sendo dever do Estado a sua garantia. Portanto, ao ampliar o ensino fundamental para 9 anos, incluindo as crianças de 6 anos, o poder público não pode fazê-lo parcial ou facultativamente, como ocorre em algumas propostas atuais. Cabe ao poder público oportunizar o acesso de todos os alunos que se enquadrem nos requisitos, podendo, inclusive, ser responsabilizado pelo não oferecimento ou pela sua oferta irregular, conforme previsto no $\S 2^{\circ}$ do art. 208 da Constituição Federal (BRASIL, 2003d).

Com a sanção da Lei no. 11.274, em fevereiro de 2006 (BRASIL, 2006), o ensino fundamental de 9 anos se tornou obrigatório no Pais, com matrícula dos alunos aos 6 anos de idade, alterando os artigos 32 e 87 da Lei №. 9.394 (BRASIL, 1996). 0 art. 32 (BRASIL, 2006) passa a vigorar com a seguinte redação:

0 ensino fundamental obrigatório, com duração de 9 (nove) anos, gratuito na escola pública, iniciando-se aos 6 (seis) anos de idade, terá por objetivo a formação básica do cidadão, mediante: [...] (NR)

Assim, os Municípios, e supletivamente, o Estado e a União, deverão: matricular todos os educandos a partir dos 6 (seis) anos de idade no ensino fundamental, conforme previsto na alteração dada ao art. 87, § $3^{\circ}$, I da Lei ${ }^{\circ} .9 .394$ (BRASIL, 1996). Isso quer dizer que a obrigatoriedade para este nivel da educação básica fica estabelecida para as crianças que completarem 6 anos de idade. Essa iniciativa representa um grande avanço na realidade educacional brasileira, visto que muitas crianças nesta faixa etária não estavam incluídas na educação infantil e não tinham acesso ao ensino fundamental.

Ensaio: aval. pol. públ. Educ., Rio de Janeiro, v. 17, n. 64, p. 495-520, jul./set. 2009 
Porém, ao ser publicada a Emenda Constitucional n. 53, em 20 de dezembro de 2006, nova interpretação ocorreu no campo da obrigatoriedade escolar. Esta Emenda modificou o inciso IV do art. 208 da Constituição Federal (BRASIL, 2003d), estabelecendo que a educação infantil deve atender crianças até cinco anos de idade. Essa previsão induziu, em algumas realidades, o entendimento de que o ensino fundamental deve ser oferecido a partir dos cinco anos de idade.

A interpretação de que o ensino fundamental deve ser oferecido para crianças a partir dos 5 anos de idade não considera aspectos de extrema relevância na questão, tais como: as características próprias da faixa etária para sua inclusão na escola obrigatória, os objetivos do ensino fundamental e as possibilidades financeiras, materiais, humanas e pedagógicas dos municípios para o atendimento qualitativo da oferta.

Fica evidente que o direito à ampliação da escolaridade obrigatória é medida legal, política e educacional e deve ser avaliada como extremamente significativa em um país onde a maioria das crianças pequenas não frequentam qualquer instituição de educação formal, e que, portanto, o acesso mais cedo à escola pode contribuir significativamente para a conquista da cidadania. Porém, apenas ampliar o tempo de duração da escolaridade obrigatória, através da inclusão precoce no processo educativo, sem criar mecanismos que respeitem o direito à infância e que possibilitem a permanência e aprendizado dos alunos na escola é medida que permanece no campo da utopia.

É preciso considerar que a educação contribui significativamente para o exercício da cidadania. Por isso, é preciso entender a educação como direito de cidadania, ou seja, não basta antecipar o acesso à escola, é preciso ampliar as condições materiais da sociedade para a fruição de seus direitos e deveres.

\section{Conclusão}

0 presente texto procurou expor as relações entre direito e educação, defendendo esta última como direito de cidadania, conforme assegurado historicamente pelos documentos legais internacionais e brasileiros. Em um país de formação histórico-social baseada no clientelismo, exclusão e descompromisso governamental, a ampliação da escolaridade obrigatória - ensino fundamental de 9 anos - põe de forma explícita a preocupação em garantir um maior número de crianças no contexto escolar, mas também expõe a necessidade de rever a organização do sistema educacional brasileiro, para que a presente proposta se efetive na realidade material e não se torne, como tantas outras, mera previsão legal sem efetividade prática.

Apenas incluir mais crianças na escola, sem um planejamento politico e pedagógico pode contribuir para que o fracasso da escola brasileira seja visivel mais cedo e atinja os brasileiros ainda em processo de formação pessoal e a conquista da educação como direito de cidadania se torne distante da realidade da maioria.

Ensaio: aval. pol. públ. Educ., Rio de Janeiro, v. 17, n. 64, p. 495-520, jul./set. 2009 
Assim, essa nova forma de organização mostra-se contraditória, pois de um lado possibilita que um maior número de crianças esteja frequentando a escola e, de outro, não garante que um ano a mais possa melhorar a aprendizagem adquirida no contexto escolar. Para além das questões pontuadas, a ampliação da escolaridade obrigatória pode significar, ainda, um desrespeito pelo direito de ser criança, quando inclui precocemente as crianças na escola sem a devida reorganização pedagógica para o atendimento. Esse direito violado jamais poderá ser resgatado.

0 avanço significativo em relação ao direito à educação para todos os brasileiros, evidenciado pela ampliação da escolaridade obrigatória, pode-se tornar limitado caso não ofereça condições adequadas para o acesso, a permanência e 0 aprendizado de todos na escola, respeitando-se a faixa etária atendida e considerando-se a necessidade de formação adequada dos profissionais envolvidos no processo.

0 direito à educação no Brasil tem um longo caminho a percorrer até conseguir ultrapassar os limites impostos pelas condições existentes em seu processo de formação. Não basta o direito estar assegurado, a sua efetividade deve ser garantida em todo o território nacional. A grandeza do território brasileiro demonstra o quão árdua pode ser essa luta histórica.

\section{Referências}

ARELARO, L. R. G. 0 ensino fundamental no Brasil: avanços, perplexidades e tendências. Educação e Sociedade, Campinas, SP, v. 26, n. 92, p. 1039-1066, out. 2005. Especial. Disponivel em: <http://www.cedes.unicamp.br>. Acesso em: 31 ago. 2009.

AZEVEDO, F. et al. Manifesto dos pioneiros da educação nova. Pedagogia em Foco, Rio de Janeiro, [2007]. História da educação no Brasil: período da Segunda República. Disponivel em: <ww.pedagogiaemfoco.pro.br/heb07a.htm>. Acesso em: 1 set. 2009.

BRASIL. Constituição (1824). Constituicão Politica do Imperio do Brazil (de 25 de março de 1824). Constituição, Brasilia, DF, 2003a. Disponível em: <http:// www.planalto.gov.br/ccivil_03/constituicao/constitui\%C3\%A7a024.htm>. Acesso em: 1 set. 2009.

Constituição (1837). Constituição dos Estados Unidos do Brasil (de 10 de novembro de 1937). Constituição, Brasilia, DF, 2003b. Disponivel em: <http:// www.planalto.gov.br/ccivil_03/Constituicao/Constitui\%C3\%A7a037.htm>. Acesso em: 1 set. 2009. 
BRASIL. Constituição (1946). Constituição dos Estados Unidos do Brasil (de 18 de setembro de 1946). Constituição, Brasília, DF, 2003c. Disponível em:

$<$ www.planalto.gov.br/ccivil_03/constituicao/Constituiçao46.htm>. Acesso em: 1 set. 2009.

. Constituição (1988). Constituição da República Federativa do Brasil. 14. ed. Rio de Janeiro: DP\&A, 2003d.

Lei no. 4.024, de 20 de dezembro de 1961. Fixa Diretrizes e Bases da Educação Nacional. Diário Oficial da [República Federativa do Brasil], Brasília, DF, 27 dez. 1961 e retificado em 28 dez. 1961. Disponivel em: <www.planalto.gov.br/ccivil_03/LEIS/L4024.htm>. Acesso em: 1 set. 2009.

Lei $n^{\circ} .5 .692$, de 11 de agosto de 1971. Fixa Diretrizes e Bases para o ensino de $1^{\circ}$ e $2^{\circ}$ graus, e dá outras providências. Diário Oficial da [República Federativa do Brasil], Brasília, DF, 12 ago. 1971. Disponivel em:

<www3.dataprev.gov.br/SISLEX/.../42/.../5692.htm>. Acesso em: 1 set. 2009.

Lei $n^{\circ} .9 .394$, de 20 de dezembro de 1996. Estabelece as diretrizes e bases da educação nacional. Diário Oficial da [República Federativa do Brasil], Brasília, DF, 23 dez. 1996. Disponível em: <http://www.planalto.gov.br/ccivil_03/ LEIS/I9394.htm>. Acesso em: 1 set. 2009.

Lei $n^{\circ}$. 10.172, de 9 de janeiro de 2001. Aprova o Plano Nacional de Educação e dá outras providências. Diário Oficial da [República Federativa do Brasil], Brasília, DF, 10 jan. 2001. Disponível em: <http://www.planalto.gov.br/ ccivil_03/leis/leis_2001/l10172.htm>. Acesso em: 1 set. 2009.

Lei $n^{\circ} .11 .271$, de 6 de fevereiro de 2006. Altera a redação dos arts. 29, 30, 32 e 87 da Lei ํo 9.394, de 20 de dezembro de 1996... Diário Oficial da [República Federativa do Brasil], Brasilia, DF, 7 fev. 2006. Disponível em: <http:// www.planalto.gov.br/ccivil_03/_Ato2004-2006/2006/Lei/L11274.htm>. Acesso em: 1 set. 2009.

CURY, C. R. J. Direito à educação: direito à igualdade, direito à diferença. Cadernos de Pesquisa, São Paulo, n. 116, p. 245 - 262, jul. 2002a.

. Legislação educacional brasileira. 2. ed. Rio de Janeiro: DPCtA, $2002 b$.

FAORO, R. Os donos do poder. formação do patronato político brasileiro. 3. ed. São Paulo: Globo, 2001. 
HAIDAR, M. L. M.; TANURI, L. M. A educação pública no Brasil: dos primórdios até a primeira Lei de Diretrizes e Bases. In: MENESES, J. G. C. (Org.). Estrutura e funcionamento da educação básica: leituras. 2. ed. São Paulo: Pioneira, 1999.

IHERING, R. $A$ finalidade do direito. Rio de Janeiro, 1979. v. 1.

NEVES, L. M. W. Educação e política no Brasil de hoje. 2. ed. São Paulo: Cortez, 1999.

PARO, V. H. Administração escolar. introdução crítica. 7. ed. São Paulo: Cortez, 1996.

PONTES DE MIRANDA, Comentários à Constituição de 1946. 2. ed. Rio de Janeiro: Borsoi, 1953. t. 4.

REALE, M. Lições preliminares de direito. 16. ed. São Paulo: Saraiva, 1988.

RIBEIRO, M. L. S. História da educação brasileira: a organização escolar, 11. ed. São Paulo: Cortez: Autores Associados, 1991.

ROMANELLI, 0. 0. História da educação no Brasil (1930/1973). 8. ed. Petrópolis: Vozes, 1986.

SAVIANI, D. 0 trabalho como princípio educativo frente às novas tecnologias. In: FERRETI, C. et. al. Novas tecnologias, trabalho e educação: um debate multidisciplinar. Petrópolis, RJ: Vozes, 1994.

SHIROMA, E. 0.; MORAES, M. C. M.; EVANGELISTA, 0. Política educacional. Rio de Janeiro: DPCtA, 2000.

Recebido em: 20/04/2009

Aceito para publicação em: 28/05/2009 